\title{
The influence of channel network silting at Žitný Ostrov on the range of interaction between surface and groundwater
}

\author{
Renáta Dulovičová - Yvetta Velísková \\ Institute of Hydrology, Slovak Academy of Sciences \\ Dúbravská cesta 9, 84104 Bratislava, Slovakia \\ dulovicova@uh.savba.sk
}

\begin{abstract}
SUMMARY
The movement of water resources, especially the possibilities of their regulation by interaction between surface and groundwaters are the subject matter of attention particularly during the occurrence of extreme hydrologic situation. This work presents the overview of knowledge and results which were achieved at IH SAS in this question. It can show the ways how to optimize the adjudicated processes which emerge during the requirement of emergency intervention. The solution of this task was located at the Žitný Ostrov area because this territory with their existence of channel network is suitable for studying the surface and groundwater interaction. The channel network at Žitny Ostrov was built up for drainage and also to safeguard irrigation water. The water level in the whole channel network system has an effect on groundwater level on the Žitný Ostrov and vice versa. It was been necessary to judge the impact of the channel network silting up by bed silts on the interaction between channel network and groundwater on the Žitný Ostrov. The aim was to evaluate the changes of bed silt state of Žitný Ostrov channel network and consecutively their influence on interaction processes between groundwater and surface water along the channels in the period from 1993 to present. The measurements of bed silt thickness in Žitný ostrov channel network had been started from1993, later they continued at selected profiles of three main channels - channel Gabčíkovo-Topolníky, Chotárny channel and Komárňanský channel (for checking of the silting up variability). From 2008 the detailed field measurements of cross-section profiles aggradations along these selected three channels have been started. The objective of detailed field measurements was the determination of the silt permeability which is expressed by parameter of saturated hydraulic conductivity. This parameter was determined by two ways - as the saturated hydraulic conductivity obtained from disturbed samples of silt $K_{p}$ and as the saturated hydraulic conductivity obtained from undisturbed samples of silt $K_{n}$. In the first case the granularity of silts was determined as a first step and then was computed their $K_{p}$ from the empirical formulas according BayerSchweiger and Spacek. From undisturbed samples of silts which were extracted along the channels from top, middle and bottom layer of silts, were determined the values $K_{n}$ by the laboratory falling head method. The valid values $K_{p}$ on channel Gabčikovo-Topolniky ranged from $4,3310^{-7}$ to $4,46.10^{-5} \mathrm{~m} \mathrm{~s}^{-1}$, on Chotárny channel from $5.9810^{-5}$ to $2.1410^{-6} \mathrm{~m} \mathrm{~s}^{-1}$ and on Komárňanský channel fluctuated from $1.9310^{-6}-6.09$ $10^{-5} \mathrm{~m} \mathrm{~s}^{-1}$. The valid values $K_{n}$ on on channel Gabčikovo-Topolniky ranged from $5.2110^{-8}-4.1810^{-3} \mathrm{~m} \mathrm{~s}^{-1}$, on Chotárny channel ranged from $8.5410^{-8}-2.7010^{-4} \mathrm{~m} \mathrm{~s}^{-1}$ and on Komárn̆anský channel fluctuated from $4.7210^{-7}-1.2610^{-5} \mathrm{~m} \mathrm{~s}^{-1}$. The remarkable results were noticed by comparison of values of saturated hydraulic conductivity from disturbed and undisturbed samples $K_{p}$ and $K_{n}$. On Chotárny channel the values of silt saturated hydraulic conductivity from undisturbed samples $K_{n}$ approximately hundredfold decreased (from $10^{-6}$ to $10^{-8} \mathrm{~m} \mathrm{~s}^{-1}$ ). On Komárn̆anský channel the comparison of values $K_{p}$ and $K_{n}$ shown that the values $K_{n}$ from undisturbed samples approximately tenfold descended against $K_{p}$.

Simultaneously, the bed silts 'impact on the groundwater recharge (saturated hydraulic conductivity of silt) was also examined. Determination of the total recharge amount was done by numerical simulation (model SKOKY) and by the so-called method of interaction formulas. These two approaches were applied at the Žitný Ostrov channel network. There were field measurements performed in monitored three main channels and adjacent to obtain correct input data. These characteristics were used for simulation and computation of total recharge along the channels. The total recharge amount was calculated for four alternatives of the surface water levels in the channel and the surroundings groundwater respectively. We chose four simplified variants with the same geological conditions in surroundings area of channels, only water levels of groundwater and in channels were modified. The results of the simulations seem to show greater impact of the silt in the case of outflow from the channels to the surroundings than the inflow into the channel from the surroundings.
\end{abstract}

Keywords: bed silts, cross-section profile, surface and groundwater interaction, granularity curve, saturated hydraulic conductivity

\section{INTRODUCTION}

At present in context with climatic change the enlarged demand of sufficient information about mutual interaction between surface and groundwater comes up. The processes related with this question are stick out to importancy especially during hydrological extremes - in drought period, furthermore in flood period and also during accidental ecological disasters with effect of contamination of surface stream or groundwater. Detailed understanding and consequential active regulation of surface and groundwater and their regimes is natural necessity for watermanagement on all the world.
The various aspects of surface and groundwater interaction as e.g. the solution of changes of groundwater resources, the uncertainty of interaction quantification or solution of substances transport by mutual interaction surface and groundwater were researched by several authors (Chen $\mathrm{Xi}$ and Chen Xunhong, 2003; Lautz and Siegel, 2006; Baroková and Šoltész, 2011; Rassam et al., 2013; Johnson et al., 2014), also innovational ways of measurement of parameters and interaction rate with various level of exactness occured (Hatch et al., 2006; Kalbus et al., 2006; Weitz and Demlie, 2013).

Questions which are related with problems of surface and groundwater interaction, have been already 
solved on IH SAS in past time (Kosorin, 1997, 2001, 2006; Burger 2005, 2008; Velísková et al., 2010; Dulovičová et al., 2013, etc.). This task was located at Danube Lowland, exactly Žitný Ostrov area, because this territory is very suitable for study of surface and groundwater interaction. It is area of occurrence of the largest resources of drinkable water at Slovakia, but also it is area which is greatly endangered by potential contamination from agriculture production, industry, urban agglomerations, road communications and junkyards of industrial waste. The surface water of Danube River can be also potencial source of region contamination (Čelková, 2013; Kováčová and Velísková, 2012). Thanks to flat texture of this territory and the existence of established channel network Žitný Ostrov became optimal locality for exploration of mutual interaction between surface and groundwaters.

\section{MATERIALS AND METHODS}

Žitný Ostrov (ŽO) lies between two branches of the Danube River, on which this river is divided just below the Slovak capital Bratislava: the Danube and the Small Danube - Figure 1 .

Figure 1: Site of Žitný Ostrov at Slovakia

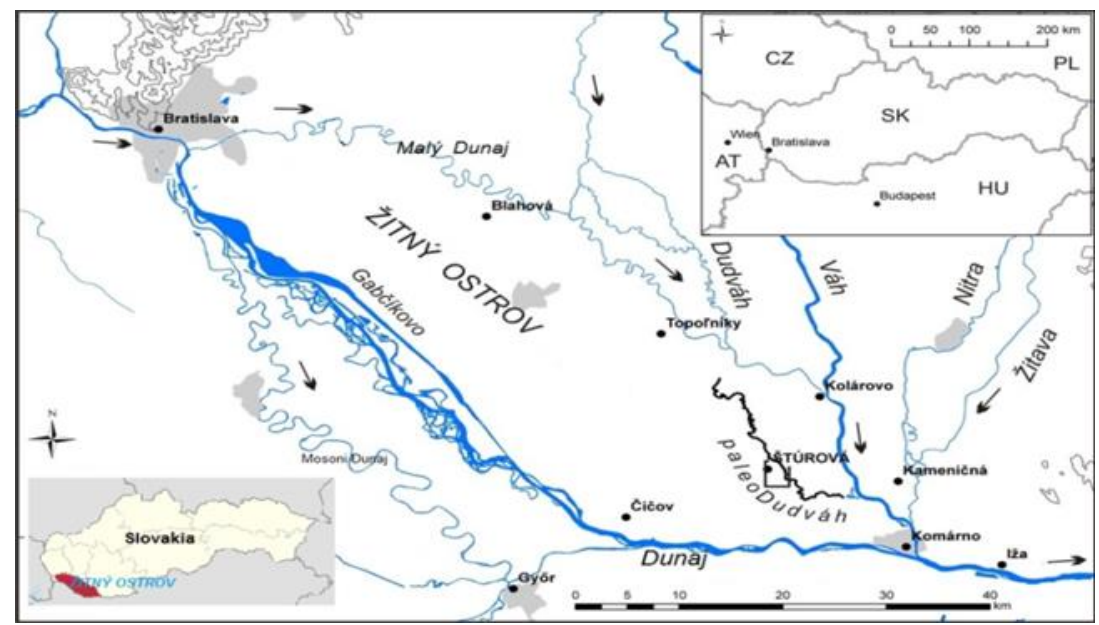

The area of ŽO is approximately $2000 \mathrm{~km}^{2}$ and represents about $4 \%$ of the Slovak territory. Its average slope is only about $2.510^{-4}$ and this was one of the reasons for building the channel network within this area - Figure 2 left. The channel network was built up for drainage and also to safeguard irrigation water. The water level in the whole channel network system has effect to groundwater level on the $\breve{Z} O$ and in reverse. It was been necessary to judge the impact of channel network silting up by bed silts on the interaction between channel network and groundwater on the ŽO. Aim of this work was to evaluate the changes of bed silt state of ŽO channel network and consecutively their influence on interaction processes between groundwater and surface water along the channels in the period from 1993 to present.

\section{Measurements of channel network aggradation}

The measurements of bed silt thickness in $\check{Z} O$ channel network started in 1993 at the channels: Aszód, Gabčíkovo-Topol'níky, Aszód-Čergov, Čergov-
Komárno, Čalovo-Holiare and Holiare-Kosihy. Then in 2004 the measurements continued at selected profiles of three main drainage channels - channel GabčíkovoTopol'níky, Chotárny channel and Komárňanský channel, for checking of the silting up variability Figure 2 right.

From 2008 the detailed field measurements of cross-section profiles aggradations along these three channels have been done to present. The silting up was measured on the presignify determined cross-section profiles of these channels. The transverse distance of aggradation measurement in every profile was $1.0-2.0$ $\mathrm{m}$. The distance of cross-section profiles along single channels ranged from 2.0 to $5.0 \mathrm{~km}$, with respect to given cross-section profile readability. Each measurement was realized from an inflatable rubber boat by simple measuring equipment (hole probe) Figure 3 up and then by echo-sounder Lowrance HDS10 and EA400/SP - Figure 3 down. 
Figure 2: Scheme of channel network at ŽO (left) and situation of three main channels at ŽO - channel Gabčíkovo-Topol'níky, Chotárny channel and Komárňanský channel (right)
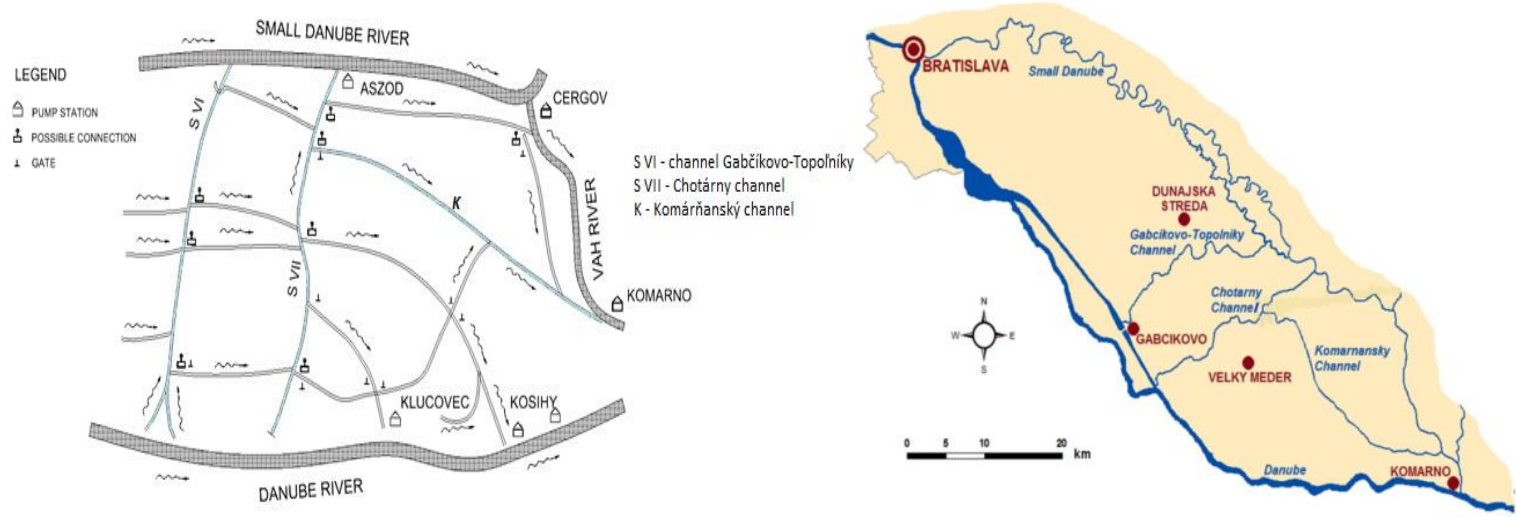

Figure 3: Aggradation measuring equipments

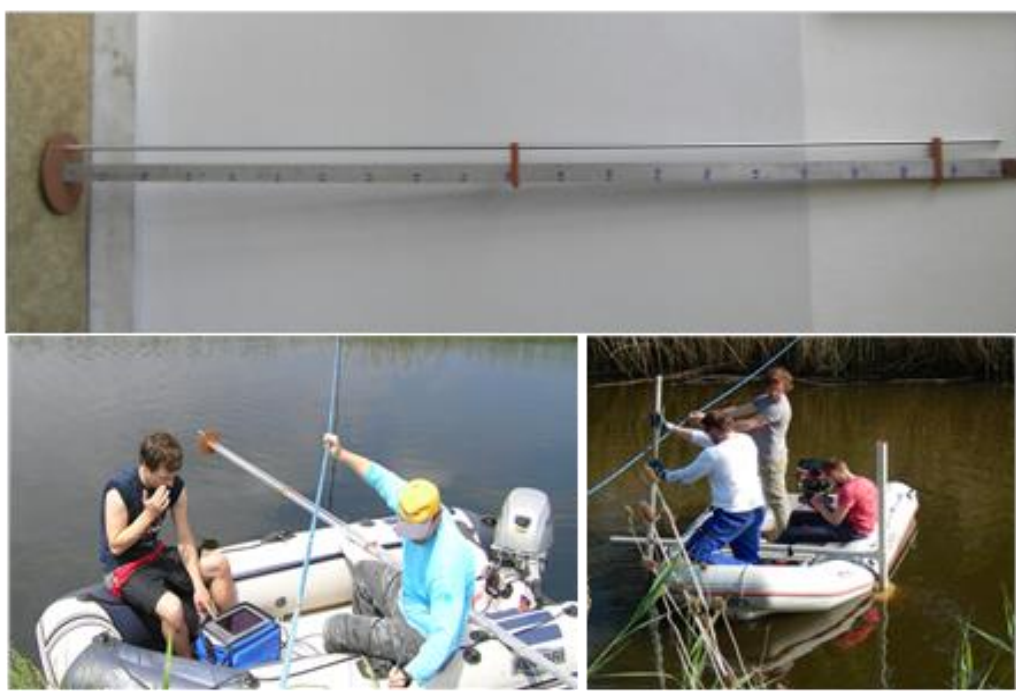

Simultaneously the samples of silts were extracted from several cross-section profiles - by auger (in 2004, 2008) and by beeker sampler (from 2014 to present) see at Figure 4. The samples were extracted from top, middle and bottom of silt layer.

Figure 4: Measuring equipments for silt samples extraction auger (left) and beeker sampler (right)
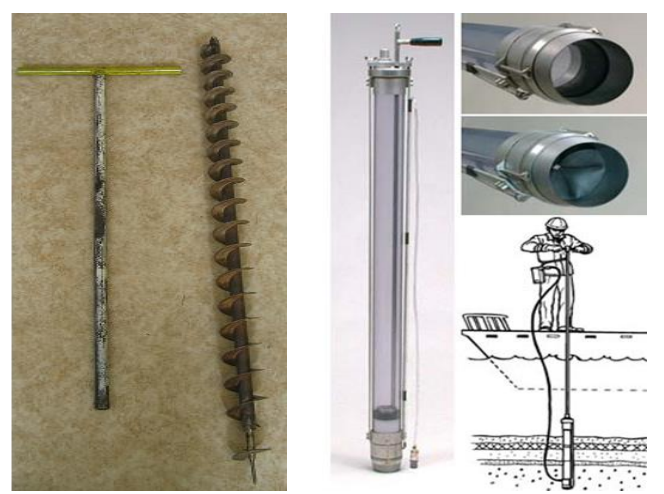

\section{Hydraulic conductivity of silts}

The objective of detailed field measurements was the determination of the silt permeability, which is expressed by parameter of saturated hydraulic conductivity (SHC). This parameter was determined by two ways - firstly as SHC from disturbed samples of silt $-K_{p}$ and secondly as SHC from undisturbed samples - $\mathrm{K}_{\mathrm{n}}$. In the first case initially the granularity of silts was determined and then was computed their $\mathrm{K}_{\mathrm{p}}$ according Bayer-Schweiger and Spacek formulas which are quoted in (Mucha, Šestakov, 1987 and Špaček, 1987). These relationships are functions of $\mathrm{d}_{10}-$ particle diameter in $10 \%$ of soil mass $(\mathrm{m})$ and $\mathrm{d}_{60}-$ particle diameter in $60 \%$ of soil mass (m). Both of them were determined from granularity curves of the silts. The empirical relationships for determination of SHC by Beyer-Schweiger and by Špaček also depend on different conditions of validity for their application (quoted e.g. in Dulovičová et al., 2016). In the second case the values $K_{n}$ from undisturbed samples were determined by the laboratory falling head method. The 
detailed description and the methodology of measurement is described in previous works (Šrda et al., 2013; Dulovičová et al., 2016). The equipment with fluctuant hydraulic downslope was used for this measuremnt - Figure 5. The formula for calculation of $\mathrm{K}_{\mathrm{n}}$ depends on sample height (according scheme on Figure $5-l$ ) and also on the ratio $\mathrm{h}_{2} / \mathrm{h}_{1}$ and expired measurement time $\Delta \mathrm{t}$ :

$$
K_{n}=\frac{l}{\Delta t} \ln \frac{h 2}{h 1} \quad\left[\mathrm{~cm} \mathrm{~s}^{-1}\right]
$$

where $K_{n}$ is SHC from undisturbed silt samples, $l$ is height of silt sample and $\Delta h$ is the difference between $h_{1}$ and $h_{2}$ according scheme on Figure 5.
Figure 5: Simplified equipment for measuring of $\mathbf{K}_{\mathbf{n}}: \mathbf{1}$ sampling tube, 2 - filter paper and woven wired sieve, 3 - Petri dish, 4 - extension piece, 5 - confining ring

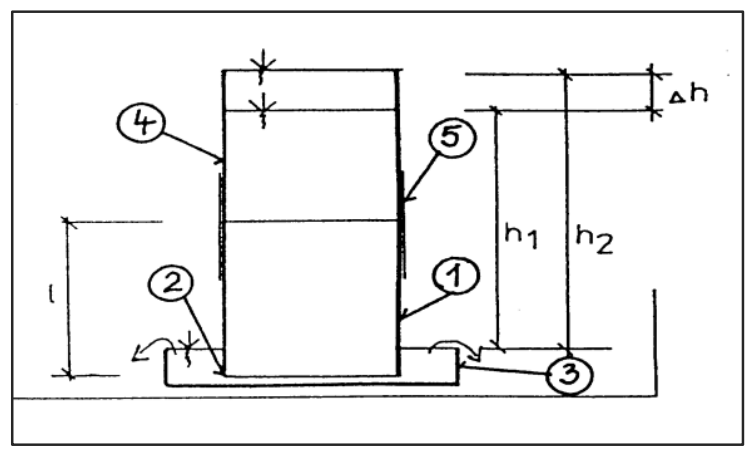

Figure 6 shows the example of silt sample extraction from inflatable rubber boat by beeker (left) and saturation of undisturbed silt samples in Kopecky rollers during laboratory falling head method (right).

Figure 6: Extraction of silt sample from channel by beeker (left), saturation of undisturbed samples during laboratory falling head method (right)

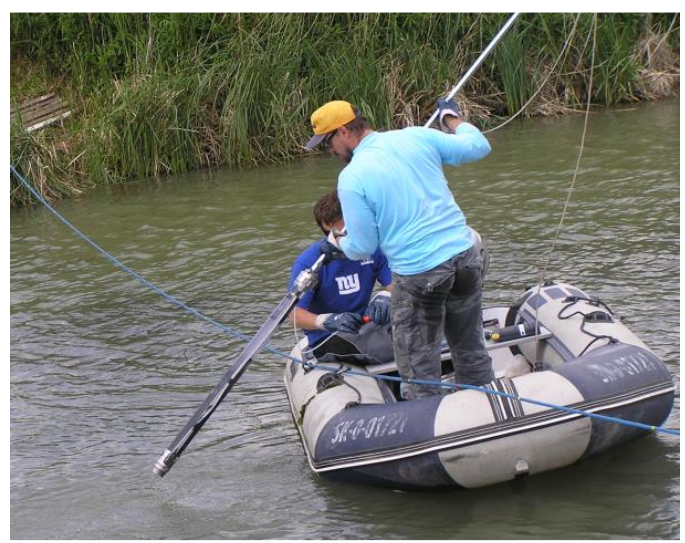

Impact of silting up to range of interaction between surface and groundwater

The interaction of surface-water bodies with groundwater systems is governed by the positions of the water bodies relative to the ground-water flow system, the characteristics of surface-water beds and underlying geological materials, it depends on relation between the groundwater head at the stream interface and the stream stage. A stream may gain water from the seepage of groundwater through the stream bed (gaining stream; stream stage < groundwater head) or lose water to groundwater by outflow through the stream bed (losing stream; stream stage > groundwater head). The exchange of water quantity between open channel and groundwater reservoir is realized through their contact areas. The seepage from the groundwater into the stream (or conversely) is a key hydraulic characteristic, which is given as an inflow/outflow in $\mathrm{m}^{3} \mathrm{~s}^{-1}$ over the channel bottom area, allocated on one meter of channel length. This lateral flow $\mathrm{q}_{\mathrm{bm}}$ in $\mathrm{m}^{2} \mathrm{~s}^{-1}$ is expressed by continuity equation:

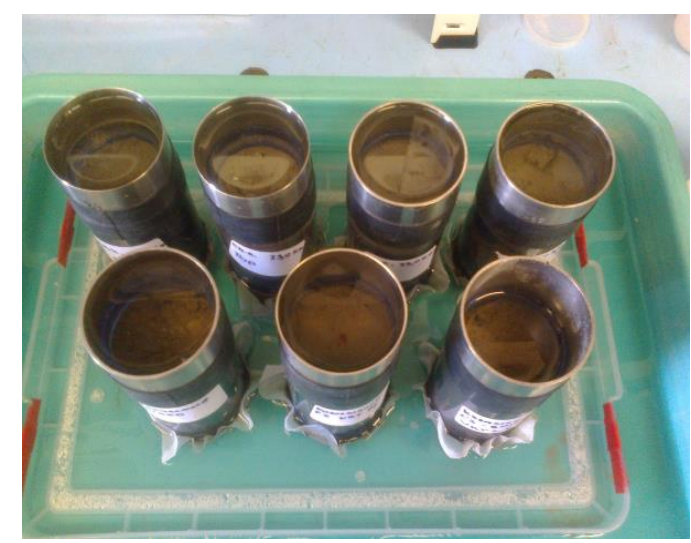

$$
q_{b m}=\frac{\partial S}{\partial t}+\frac{\partial Q}{\partial x}
$$

where left element of this equation means partial variation of discharge cross-section $\mathrm{S}$ in partial time $\mathrm{t}$ and right element represents the partial change of discharge $Q$ along partial channel section $X$. The intensity of this characteristic determines the stream impact onto the surrounding groundwater and conversely. The discharge $\mathrm{q}_{\mathrm{bm}}$ constitutes the input characteristic in case of surface water or the boundary condition in case of groundwater. In our case was used the three dimensional hydrodynamic model SKOKY for simulation of groundwater and surface water flow in their mutual interaction which was developed at the IH SAS Bratislava by Dr. Kosorin (Kosorin, 2001). Model SKOKY is based on a mathematical model, consisting from equations:

$$
\operatorname{grad} \mathrm{P}+\mathrm{v} / \mathrm{k}=0
$$


where $P$ is pressure function (potencial $P=y+p / g \rho+$ const), $\mathrm{v}$ is a velocity vector, $\mathrm{p}$ is the hydrodynamic pressure, $\mathrm{y}$ is the vertical coordinate and $\mathrm{k}$ is hydraulic conductivity coefficient.

$$
\text { and } \quad \operatorname{div} v=0
$$

Model is completed ordinarily with correctly stated boundary conditions (the actual measured values from existing databases of observation were used).

Also there was used the so-called method of interaction formulas for determination of water recharge. Kosorin, 2001 derived a general relation for the inflow (from groundwater into surface water) or outflow (from surface water into groundwater):

$$
\mathrm{q}_{\mathrm{bm}}=\mathrm{a}_{1} \varphi_{1}+\mathrm{a}_{2} \varphi_{2}+\mathrm{a}_{3} \varphi_{3}+\ldots .+\mathrm{a}_{\mathrm{i}} \varphi_{\mathrm{i}}
$$

where $\varphi_{1}, \varphi_{2}, \ldots, \varphi_{\mathrm{i}}$ are the interaction formulas and $a_{1}, a_{2}, \ldots, a_{i}$ are their parameters which we had to find. The interaction formulas include the influence of variable parameters for the evaluation of the inflow/outflow, they depend on the water level in the stream and equally on the groundwater level in the adjacent area. This relationship is expressed as:

$$
\varphi_{\mathrm{i}}=\mathrm{f}\left(\mathrm{h}, \mathrm{H}_{0}, \mathrm{H}_{1}, \mathrm{H}_{2}\right)
$$

where $\mathrm{H}_{1}$ is groundwater level in input cross-section $\mathrm{X}_{1}, \mathrm{H}_{2}$ is groundwater level in output cross-section $\mathrm{X}_{2}$. The course of groundwater flow is in direction axix $\mathrm{X}$, from $X_{1}$ to $X_{2}$. Cross sections $X_{1}$ and $X_{2}$ are at symmetrical distances from the cross section centre line and $\mathrm{H}$ is the sum of the groundwater body thickness from impermeable bedrock to a channel bottom and depth of water in the stream, refer to Figure 7.

Figure 7: Schema of mutual interaction between the surface flow and the groundwater for a symmetrical stream cross section gaining stream (left) and losing stream (right)
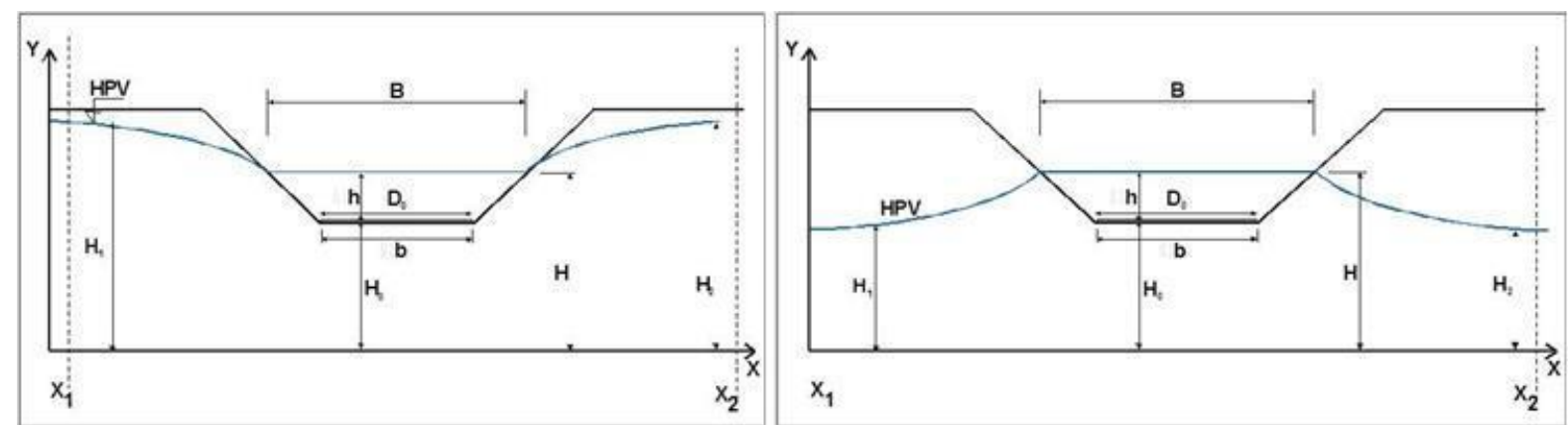

This figure presents the schema of mutual interaction between the surface flow and the groundwater for a symmetrical stream cross section with water depth $h$ in case of gaining stream. Scheme for losing stream is the same, only with one changed detail: $\left(\mathrm{H}_{1}=\mathrm{H}_{2}\right)<\left(\mathrm{H}=\mathrm{H}_{0}+\mathrm{h}\right)$. The silt thickness $\mathrm{D}_{0}$ is symmetrical across whole bottom width. HPV is the groundwater level. The impact of geological characteristics of the surroundings at cross section and its geometrical parameters is expressed as:

$$
\mathrm{a}_{\mathrm{i}}=\mathrm{f}_{\mathrm{i}}\left(\mathrm{H}_{0}, \mathrm{~b}, \mathrm{k}_{\mathrm{fGW}}, \mathrm{k}_{\mathrm{fS}}\right)
$$

where $\mathrm{i}=1,2,3, \ldots, \mathrm{k}_{\mathrm{fGW}}$ is saturated hydraulic conductivity of the groundwater body, $\mathrm{k}_{\mathrm{fS}}$ is saturated hydraulic conductivity of the bed silts of a single cross section and $b$ is the channel width in the bottom of this cross-section.

Four variants were simulated and compared. Variant I. was a symmetrical double-sided groundwater inflow into a symmetrical stream cross-section with the water depth $\mathrm{h}$. The value of the total recharge was: $\mathrm{q}_{\mathrm{I}}=$ $+\mathrm{q}_{1}+\mathrm{q}_{2}\left(\mathrm{~m}^{2} \mathrm{~s}^{-1}\right)$, where $\mathrm{q}$ is total outflow/inflow from/into a stream, $\mathrm{q}_{1}$ is discharge through input cross section $\mathrm{X}_{1}$ and $\mathrm{q}_{2}$ is discharge through output cross section $\mathrm{X}_{2}$. Variant II. was a symmetrical double-sided outflow from a symmetrical stream cross-section (with water depth $h$ ) to the groundwater, the total recharge was: $\mathrm{q}_{\text {II. }}=-\mathrm{q}_{1}-\mathrm{q}_{2}\left(\mathrm{~m}^{2} \mathrm{~s}^{-1}\right)$. All variants used the groundwater level in the input cross-section $\mathrm{X}_{1}$ identical with the groundwater level in the output cross section $\mathrm{X}_{2}$, that means $\mathrm{H}_{1}=\mathrm{H}_{2}$ and at the same time the water depth in stream is $\mathrm{h}$. Variant III. was a doublesided groundwater inflow into a symmetrical stream cross-section with the same groundwater levels $\mathrm{H}_{1}=\mathrm{H}_{2}$ and with water depth in the stream $\mathrm{h} / 2$. The relation for the groundwater recharge for this variant is the same as for variant I., only water level in the cross section is $\mathrm{h} / 2$. Variant IV. was a symmetrical double-sided outflow from a symmetrical stream cross-section with water depth $2 \mathrm{~h}$ and with the same groundwater levels $\mathrm{H}_{1}=\mathrm{H}_{2}$. The recharge for this variant is the same as in variant II., only the water level in the cross section is $2 \mathrm{~h}$.

\section{RESULTS AND DISCUSSION}

According to results of measurements at these three selected channels during the monitored period 1993 to 2018 it could be demonstrated that on channel Gabčíkovo-Topol'níky was the big fluctuation in silting up, but at the same time significantly larger aggradation 
in its middle part and in its lower part (outfall to Danube river) is evident. On Chotárny channel was observed also variation in aggradation of channel and about from its middle part was found slightly increased trend of silting up with growing stream log. The results of silting up measurements at these two selected channels are demonstrated on Figure 9.

Figure 9: Example of average silt thickness comparison during monitored period - at channel Gabčíkovo-Topol'níky (left) and Chotárny channel (right)

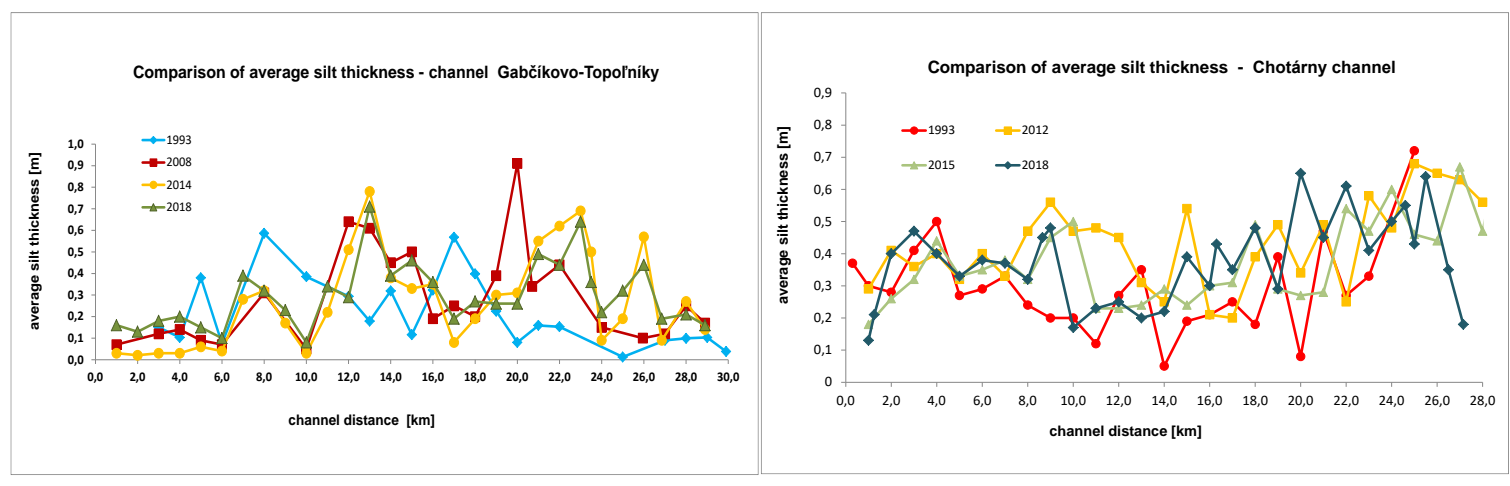

On Komárňanský channel also was observed fluctuation in aggradation of channel and also is evident softly increased trend of silting up with growing stream log from middle part of this channel which was repeated during whole monitored period 1993 to 2016, but on this channel were not so large aggradation deflections as for before mentioned channels. The presumed linear increasing of silting up did not confirmed. In generally the channel network aggradation gradually enlarged (excepting local parts in which the purification was carried on) and the silt thicknesses increased - Figure 10.

Figure 10: Course of average silt thickness during monitored period at Komárňanský channel

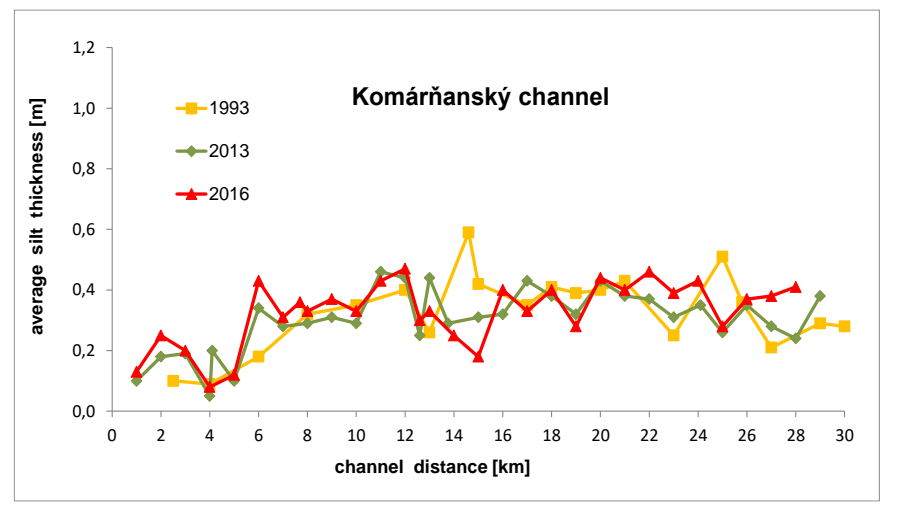

The results of assessment of SHC of silts from disturbed samples $\mathrm{K}_{\mathrm{p}}$ which were calculated according to Bayer-Schweiger and Spacek formulas, are following. The valid values $K_{p}$ on GabčíkovoTopol'níky channel ranged from $6.9910^{-9}$ to $1.0810^{-4} \mathrm{~m} \mathrm{~s}^{-1}$, on Chotárny channel from $5.9810^{-5}$ to $2.1410^{-6} \mathrm{~m} \mathrm{~s}^{-1}$ and on Komárňanský channel fluctuated from $1.9210^{-6}-6.0910^{-5} \mathrm{~m} \mathrm{~s}^{-1}$ (Dulovičová et al., 2016; Dulovičová et al., 2018).

The results of assessment of SHC of silts from undisturbed samples $\mathrm{K}_{\mathrm{n}}$ which were found out by falling head method and calculated according to the Eq. 1 , are following. The values $\mathrm{K}_{\mathrm{n}}$ on GabčíkovoTopol'níky channel ranged from $5.2110^{-8}$ to $4.1810^{-3}$ $\mathrm{m} \mathrm{s}^{-1}$, on Chotárny channel ranged from $8.5410^{-8}-2.7$ $10^{-4} \mathrm{~m} \mathrm{~s}^{-1}$ and on Komárňanský channel these values fluctuated from $4.7210^{-7}-1.2610^{-5} \mathrm{~m} \mathrm{~s}^{-1}$ (Dulovičová et al., 2016; Dulovičová et al., 2018).

We made also the comparison of SHC values from disturbed and undisturbed samples of silts. On Chotárny channel there were detected hundredfold lower values for undisturbed samples $\left(K_{n}\right)$ opposite values of disturbed samples $\left(\mathrm{K}_{\mathrm{p}}\right)$. By comparison of top and bottom layer of silts was detected that top layer of silt had ten times higher values of $K_{n}$ opposite to $K_{p}$, the bottom layer had twenty times higher values of $K_{n}$ opposite $\mathrm{K}_{\mathrm{p}}$. On Komárn̆anský channel was the value of $K_{n}$ ten times lower opposite $K_{p}$, there was detected also the decrease of values $K_{n}$ opposite $K_{p}$ in both layers - in top and bottom layer, too. The illustration of comparison of valid values $\mathrm{K}_{\mathrm{p}}$ and $\mathrm{K}_{\mathrm{n}}$ on Komárňanský channel is represented at Figure 11. 


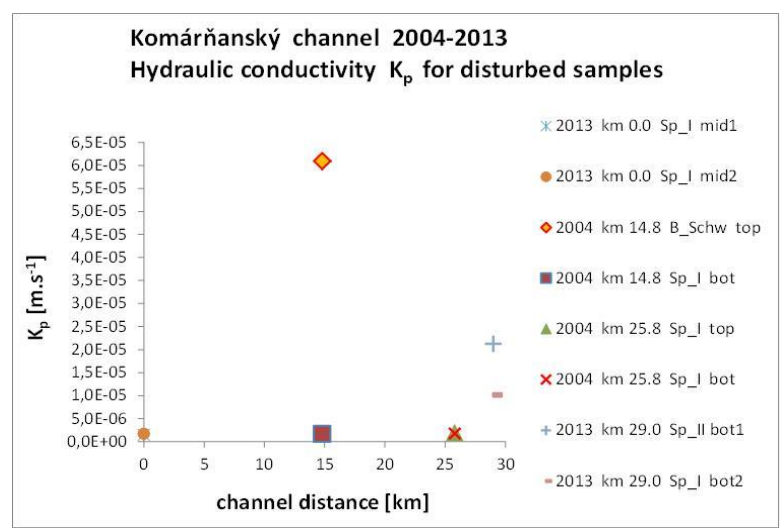

Lastly the impact of bed silts in channel on surroundings groundwater aquifer through their mutual interaction and recharge amount was evaluated. Two ways for computation of water amount were applied: model SKOKY and method of interaction functions. We calculated recharge for 4 hydrological variants, in which we used gained results from field measurements described above. At first we calculated it with model SKOKY and then we had to calculate unknown interaction formulas parameters $a_{1}-a_{4}$ for each crosssection profiles. The calculation of parameters $a_{i}$ was made by matrix method solution of linear equations system. When the difference between $q=(S K O K Y)$ and $q=f\left(\varphi_{i}\right)$, which was calculated by interaction formulas,

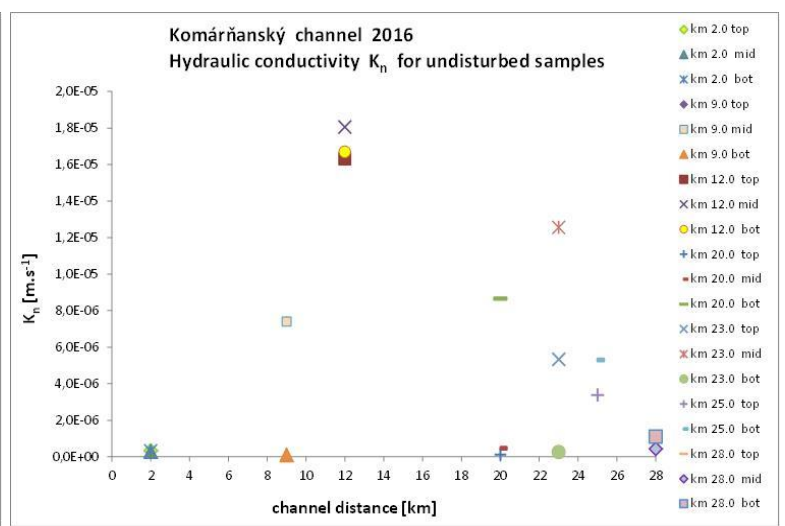

was negligible (less then $10 \%$ ), we considered selected number of interaction formulas as sufficient. When the difference was not negligible (differences were higher then $20 \%$ ), we could not consider the calculation as sufficient, that means we recommended increase the number of interaction formulas and to input another dependencies. Because our intention was judgement of sediment influence on recharge, so we did not solve number of interaction formulas and accuracy of this approach. The recharge calculated through interaction formulas, of which differences were higher then $20 \%$, we did not accept for judgement. The example of total recharge quantities in Chotárny channel from all 4 variants is in Table 1.

Verification of interaction formulas parameters validity for total recharge quantities in Chotárny channel (Dulovičová et al., 2013)

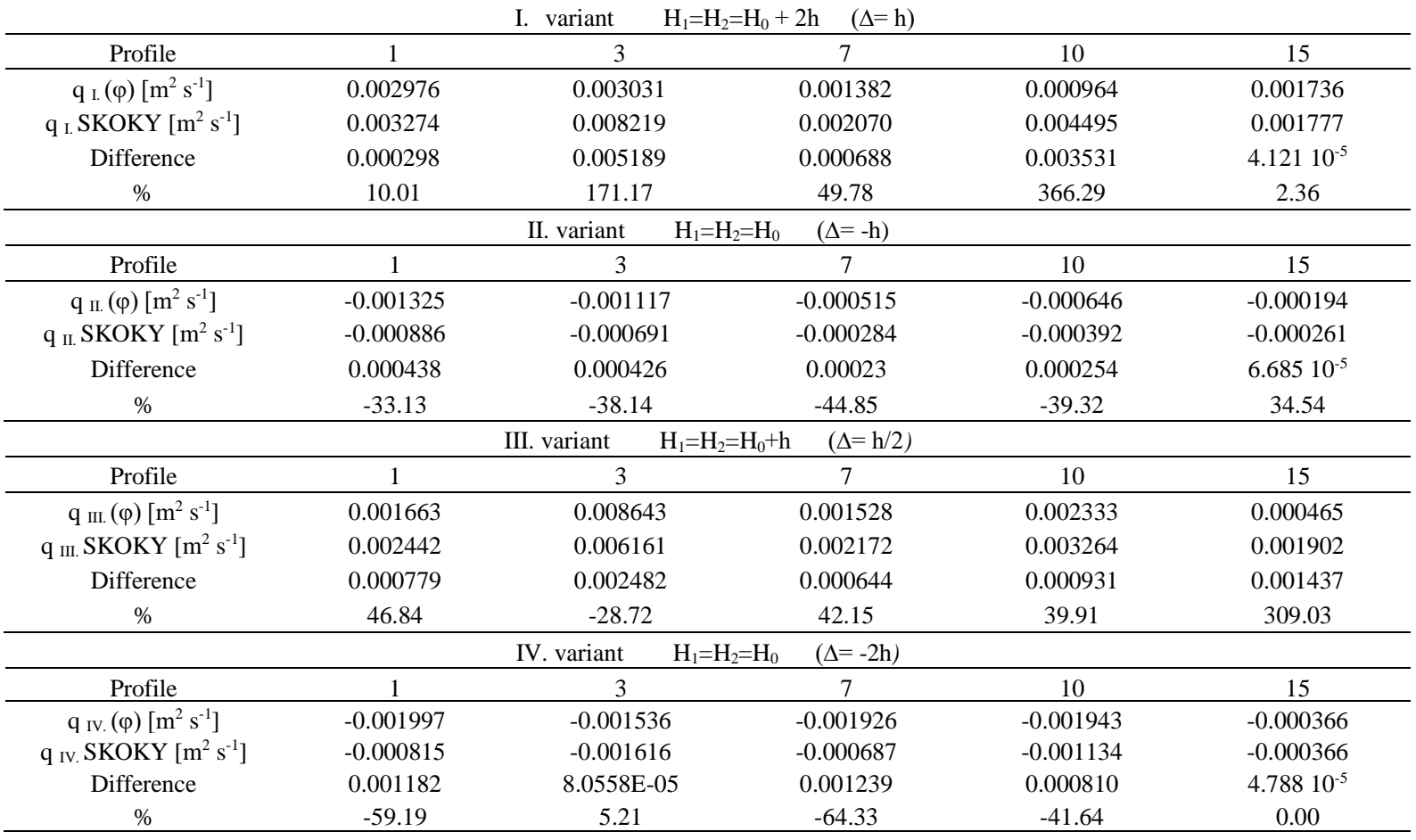


The values of total recharges from all four variants are in this table. Profiles, in which it was calculated, were distributed along the whole Chotárny channel.

\section{CONCLUSIONS}

The aim of this paper was to analyse and evaluate the impact of bed sediments quantity and its distribution along drainage channel on mutual interaction of water level in channel and in surrounding groundwater. Locality, at which this problem was solved, was the area of channel network and its surroundings at ŽO. The silt thicknesses from 1993 to 2018 has been changed as show Figure 9 and Figure 10. According to results of measurements it could be demonstrated that on all three channels during the monitored period was the big fluctuation in silting up, but at the same time significantly larger aggradation in their middle and lower part is evident. The presumed linear increasing of silting up did not confirmed. Generally we can remark that channel network aggradation gradually enlarges (excepting local parts in which the purification was carried on) and the silt thicknesses increased. Also the volume of silts extended. Our research is useful for channels' maintenance program purposes. The approximate estimates of the sediment depositions will facilitate to predict future silting up in the channels and serve as a planning tool.
Determination of the total recharge amount was done by a numerical simulation (model SKOKY) and by the so-called method of interaction formulas, both approaches were applied at ŽO channel network. The field measurements were performed in monitored three main channels and adjacent to obtain correct input data. The characteristics of SHC - $K_{p}$ and $K_{n}$ were used for simulation and computation of total recharge along these channels. The total recharge amount was calculated for 4 alternatives of the surface water levels in the channel and the surroundings groundwater respectively. We chose four simplified variants with the same geological conditions in surroundings area of channels, only water level of groundwater and in channels were modified as shows Figure 11. The results of the simulations and computation of total recharge along these channels seem to show greater impact of the silts in the case of outflow from the channels to the surroundings than the inflow into the channel from the surroundings. The silting information in the channels supplemented by values of total recharge amount can be helpful for regulation of groundwater level in surroundings of the channels.

\section{ACKNOWLEDGEMENTS}

This work was supported by the contract VEGA02/0025/19 and APVV-14-0735.

\section{REFERENCES}

Baroková, D.-Šoltész, A. (2011): Drainage and Infiltration Resistance of Rivers - Element of Interaction Between Surfaceand Groundwater. In: Current events in hydraulic engineering. Wydawnictwo Politechniki Gdańskiej, Gdańsk, 2011.

Beeker Sampler Manual, Eeijkelkamp Soil \& Water, http://www.ekotechnika.cz/uploaded/files/P1.40NW\%20opmaa k\%2098-103.pdf\#page $=1$

Burger, F. (2005): Model prúdenia podzemnej vody v pririečnom zvodnenom kolektore pri nízkej hladine vody v Dunaji. Acta Hydrologica Slovaca, Vol. 6, No. 2, 2005, 236-246.

Burger, F. (2008): Závislosti fluktuácie hladiny podzemnej vody pririečnych území od zmien hladín v riekach. Acta Hydrologica Slovaca, Vol. 9, No. 2, 2008, 274-284.

Chen, Xi-Chen, Xunhong (2003): Stream water infiltration, bank storage and storage zone changes due stream-stage fluctuations, Journal of Hydrology, vol. 280, 246-264.

Čelková, A. (2013): Numerické modelovanie transportu neadsorbujúcich kontaminantov $\mathrm{V}$ podzemnej vode na Čenkovskej nive, Acta Hydrologica Slovaca, Vol. 14, No. 1, 110-116.

Dulovičová, R.-Velísková, Y.-Bara, M.-Schügerl, R. (2013) Stanovenie vplyvu hrúbky nánosov pozdíž Chotárneho kanála na interakciu povrchových a podzemných vôd v jeho okolí, Acta Hydrologica Slovaca, Roč. 14, č. 1, 126-134.

Dulovičová, R.-Velísková, Y.-Koczka Bara, M.-Schügerl, R. (2013): Impact of Silts Distribution along Chotárny Channel on Recharge Water Amounts, European Water 44: 23-31, (C) 2013 E.W. Publications
Dulovičová, R.-Velísková, Y.-Schügerl, R. (2016): Hydraulická vodivost' nánosov Chotárneho kanála na Žitnom ostrove, Acta Hydrologica Slovaca, Roč. 17, č. 2, 149-156.

Dulovičová, R.-Velísková, Y.-Schügerl, R. (2018): Hydraulická vodivost' dnových nánosov na Komárňanskom kanáli - ŽO, Acta Hydrologica Slovaca, Roč. 19, č. 1, 117-125.

Dušek, P.-Velísková, Y. (2014): Hydrological and hydrogeological conditions at Žitný ostrov channel network area. Acta Hydrologica Slovaca, roč. 15, č. 2, 361-369.

Hatch, Ch. E.-Fisher, A. T.-Revenaugh, J. S.-Constantz, J.-Ruehl, Ch. (2006): Quantifying surface water-groundwater interactions using time series analysis of streambed thermal records, Water Resources Research, Volume 42, Issue 10

Johnson, Z. C.-Warwick, J. J.-Schumer, R. (2014): Factors affecting hyporheic and surface transient storage in a western U.S. river, Journal of Hydrology, vol. 510, 325-339.

Kalbus, E.-Reinstorf, F.-Schirmer, M. (2006): Measuring methods for groundwater - surface water interactions, Hydrology \& Earth System Sciences, Vol. 10, Issue 6, 873-887.

Kosorin, K. (1997): Spatial groundwater dynamics of the Rye Island aquifer. Journal of Hydrology and Hydromechanics, Vol. 45, 348-364.

Kosorin, K. (2001): K metodickým a aplikačným problémom modelovania pohybu povrchových a podzemných vôd vo vzájomnej interakcii, Acta Hydrologica Slovaca, Roč. 2, č. 2, 308-312.

Kosorin, K. (2006): Počítačové prostriedky simulácie a hodnotenia regulácie hladinového režimu povrchových a podzemných vôd 
vzájomnou interakciou. Acta Hydrologica Slovaca, Vol. 7, No. 2, 232-238.

Kováčová, V.-Velísková, Y. (2012): The risk of the soil salinization of the eastern part of Žitný ostrov. Journal of Hydrology and Hydromechanics, Vol. 60, No. 1, 57-63.

Lautz, L. K-Siegel D. I. (2006): Modeling surface and ground water mixing in the hyporheic zone using MODFLOW and MT3D, Advances in Water Resources, Volume 29, Issue 11, 1618-1633.

Mucha, I.-Šestakov V. M. (1987): Hydraulika podzemných vôd. Alfa, Bratislava.

Rassam D. W.-Peeters L.-Pickett T.-Jolly I.-Holz L. (2013) Accounting for surface-groundwater interactions and their uncertainty in river and groundwater models, A case study in the Namoi River, Australia, Environmental Modelling \& Software, vol. 50, 108-119.
Šurda, P.-Štekauerová, V.-Nagy, V. (2013): Variability of the saturated hydraulic conductivity of the individual soil types in the area of the Hron catchment. Növénytermelés, Vol. 62, supplement, 323-326.

Špaček, J. 1987. Stanovení koeficientu filtrace z totálních křivek zrnitosti. Meliorace, 23, č.1, s. 1-13.

Velísková, Y.-Dulovičová, R.-Štekauerová, V. (2010): Vzájomné pôsobenie povrchových a podzemných vôd v krajine. Životné prostredie, Vol. 44, No. 6, 313-318.

Weitz, J.-Demlie, M. (2013): Conceptual modelling of groundwatersurface water interactions in the Lake Sibayi Catchment, Eastern South Africa, Journal of African Earth Sciences, http://dx.doi.org/10.1016/j.jafrearsci.2013.11.018. 
